\title{
SISTEM INFORMASI PENJUALAN BATU KAPUR MENGGUNAKAN METODE TECHNOLOGY ACCEPTANCE MODEL (TAM) PADA CV. XYZ BERBASIS WEB
}

\author{
Achmad Noeman 1), Hendarman Lubis 2), \\ Jurusan Teknik Informatika, Fakultas Teknik, Universitas Bhayangkara Jakarta Raya \\ E-mail : achmad.noeman@dsn.ubharajaya.ac.id 1), hendarman.lubis@dsn.ubharajaya.ac.id 2),
}

\begin{abstract}
Abstrak
Perkembangan bidang teknologi informasi berkembang sangat cepat. Perusahaan yang bergerak dibidang jasa atau penjualan akan selalu berinovasi dalam menghadapi persaingan dengan memanfaatkan fasilitas teknologi yang berkembang saat ini. Sistem informasi penjualan menggunakan teknologi berbasis web dapat memberikan kemudahan admin dalam pencatatan data-data penjualan agar proses pembuatan laporan penjualan lebih mudah serta memberikan kemudahan kepada pelanggan untuk melakukan transaksi pembelian batu kapur. Penelitian ini menggunakan metode waterfall yang bertujuan dalam proses pengembangan perangkat lunak berurutan, di mana kemajuan dipandang sebagai terus mengalir ke bawah melewati fase-fase perencanaan, pemodelan, implementasi, dan pengujian. Dengan memanfaatkan teknologi berbasis web bagi perusahaan akan memudahkan dalam membuat laporan, menghindari kehilangan data penjualan serta mempermudah dalam memberikan informasi penjualan batu kapur.

Kata Kunci : Teknologi Informasi, Teknologi Berbasis Web, Sistem Penjualan, metode waterfall.
\end{abstract}

\footnotetext{
Abstract

The development of information technology is developing very fast. Companies engaged in services or sales will always innovate in the face of competition by utilizing technology facilities that are currently developing. Sales information sistem using web-based technology can provide admin convenience in recording sales data so that the process of making sales reports easier and provides convenience to customers to make purchases of limestone. This study uses the waterfall method which aims at sequential software development processes, where progress is seen as continuously flowing down through the phases of planning, modeling, implementation, and testing. By utilizing web-based technology for companies it will be easier to make reports, avoid losing sales data and make it easier to provide information on the sale of limestone.
}

Keywords: Information Technology, Web Based Technology, Sales Sistem, waterfall method. 


\section{PENDAHULUAN}

Perkembangan dibidang teknologi informasi semakin pesat serta memberikan dampak yang nyata di segala aspek kehidupan masyarakat. Perkembangan teknologi internet memberikan banyak perubahan yang mampu mengubah pola hidup masyarakat terutama perilaku dalam pengambilan keputusan pembelian. Peralihan proses belanja saat ini dari pembeli ke penjual didukung dengan kecanggihan dari perkembangan teknologi informasi.

Belanja yang dulu istilahnya adalah transaksi saling bertemu penjual dan pembeli secara langsung kini sudah mulai bergeser menjadi belanja secara online, hanya dengan mengakses melalui internet yang bisa dilakukan dimana saja tanpa adanya pembatasan akses dalam mencari produk yang diinginkan, dimanapun dan kapan pun pembeli bisa melakukan itransaksi. Pada CV. XYZ bergerak dibidang penjualan batu kapur yang menjual jenis-jenis batu kapur seperti batu gamping seharga Rp. 865.000/dumptruck, batu kalsium seharga Rp. 1.250.000/dumptruck, batu pondasi seharga Rp. 825.000/dumptruck. Dimana penjualan batu kapur masih menggunakan cara konvensional seperti data-data penjualan yang masih menggunakan buku dianggap masih kurang maksimal, dengan menggunakan buku dapat menyebabkan buku tersebut hilang dan rusak. Pembuatan laporan yang masih menggunakan konvensional kurang efektif dan efisien karena jika ada data penjualan yang hilang maka akan menyulitkan pembuatan laporan. Tidak adanya konfirmasi pembayaran dari pelanggan ke penjual seperti upload foto pembayaran. Kurang cepatnya pelayanan terhadap pelanggan karena penjualannya hanya pada jam tertentu atau pada jam kerja. Selain itu juga pelanggan tidak mengetahui ketersediaan batu kapur yang ingin dibeli. Dari permasalahan tersebut penulis mengembangkan sistem informasi penjualan batu kapur yang dapat memudahkan pemilik perusahaan dalam mengelola data-data penjualan dan membuat laporan penjualan, serta pelanggan dapat upload foto pembayaran untuk memberikan informasi kepada admin jika sudah melakukan pembayaran. Selain itu, juga dapat membantu perusahaan dalam memberikan pelayanan yang optimal dalam proses penjualan batu kapur kepada pelanggan seperti penjualan yang dapat dilakukan selama 24 jam. Dan pelanggan dapat mengetahui ketersediaan batu kapur. Technology Acceptance Model (TAM) adalah suatu model penerimaan sistem teknologi informasi yang akan digunakan oleh pemakai. Metode Technology Acceptance Model (TAM) ini merupakan alat ukur penerimaan sistem teknologi yang berkaitan dengan penggunaan aplikasi oleh user. Diterapkan di CV. XYZ untuk mengetahui sejauh mana sistem tersebut dipergunakan untuk mengukur penggunaan aplikasi penjualan oleh user. Sistem informasi penjualan berbasis web menggunakan bahasa pemrograman $P H P$ (Hypertext Preprocessor) dan untuk database nya menggunakan MySQL.

\section{TINJAUAN PUSTAKA}

penulis melakukan penelitian mengenai sistem informasi penjualan batu kapur menggunakan metode technology acceptance model (tam) pada cv. xyz berbasis web. Didalam aplikasi tersebut terdapat sistem informasi penjualan batu kapur sehingga memudahkan cutomer atau pelanggan dalam melakukan pembelian batu kapur. Pada sistem tersebut memiliki konfirmasi penerimaan dana dari 
pelanggan ke penjual. Pada proses pengolahan data pembelian customer atau pelanggan mengirimkan bukti transaksi melalui foto kemudian akan dilakukan verifikasi oleh admin kemudian barang akan dikirim ke pelanggan sesuai dengan pesanan.

Metode technology acceptance model (tam) merupakan suatu model penerimaan system teknologi informasi yang digunakan oleh pemakai. Metode technology acceptance model digunakan untuk memberikan kemudahan bagi perusahaan maupun customer dengan memanfaatkan teknologi informasi. Website merupakan kumpulan-kumpulan halaman yang memuat informasi dalam bentuk digital baik berupa teks, suara, gambar dan video. Dalam membangun sebuah website diperlukan tools atau aplikasi yang mensupport bahasa HTML (HyperText Markup Language) dan PHP (Hypertext Prepocessor).

Sistem informasi penjualan batu kapur menggunakan metode waterfall yang terdiri dari analisis, desain, pengodean, pengujian dan tahapan pendukung.

\section{METODOLOGI PENELITIAN}

Dengan adanya teknologi semua informasi didapatkan dengan mudah sehingga membuat efektif dan efisien bagi penggunanya. CV. XYZ adalah perusahaan yang bergerak dalam industri penambangan batu kapur, batu kalsium dan lime stone. Metode pengembangan perangkat lunak digunakan menggunakan waterfall yakni 1 . Analisis dimana penulis mengumpulkan data yang berkaitan dengan masalahmasalah yang ada pada perusahaan dengan menggunakan teknik observasi dan wawancara. 2. Desain dari perancangan system informasi yang sesuai dengan kebutuhan pada perusahaan dengan mencari solusi dari permasalahanpermasalahan dengan cara menggunakan UML (Unified Modelling Language) serta dalam pengembangan system informasi penjualan batu kapur menggunakan PHP dan MySQL. 3. Tahap pengkodean yang hasilnya sesuai dengan kebutuhan perusahaan, penulis menggunakan software Macromedia dreamweaver. 4. Pengujian atau implementasi dengan menggunakan blackbox testing. 5. Pemeliharaan system dengan melakukan perbaikan atau maintenance jika system terjadi bug serta proses backup data pada database.

a. Perancangan proses menggunakan UML (Unified Modeling Language) untuk menggambarkan bagaimana sistem akan berjalan nantinya.

1. Usecase Diagram menggambarkan aktifitas system informasi penjualan batu kapur secara keseluruhan yang dilakukan oleh pelanggan, admin dan pemilik perusahaan.perancangan proses. 


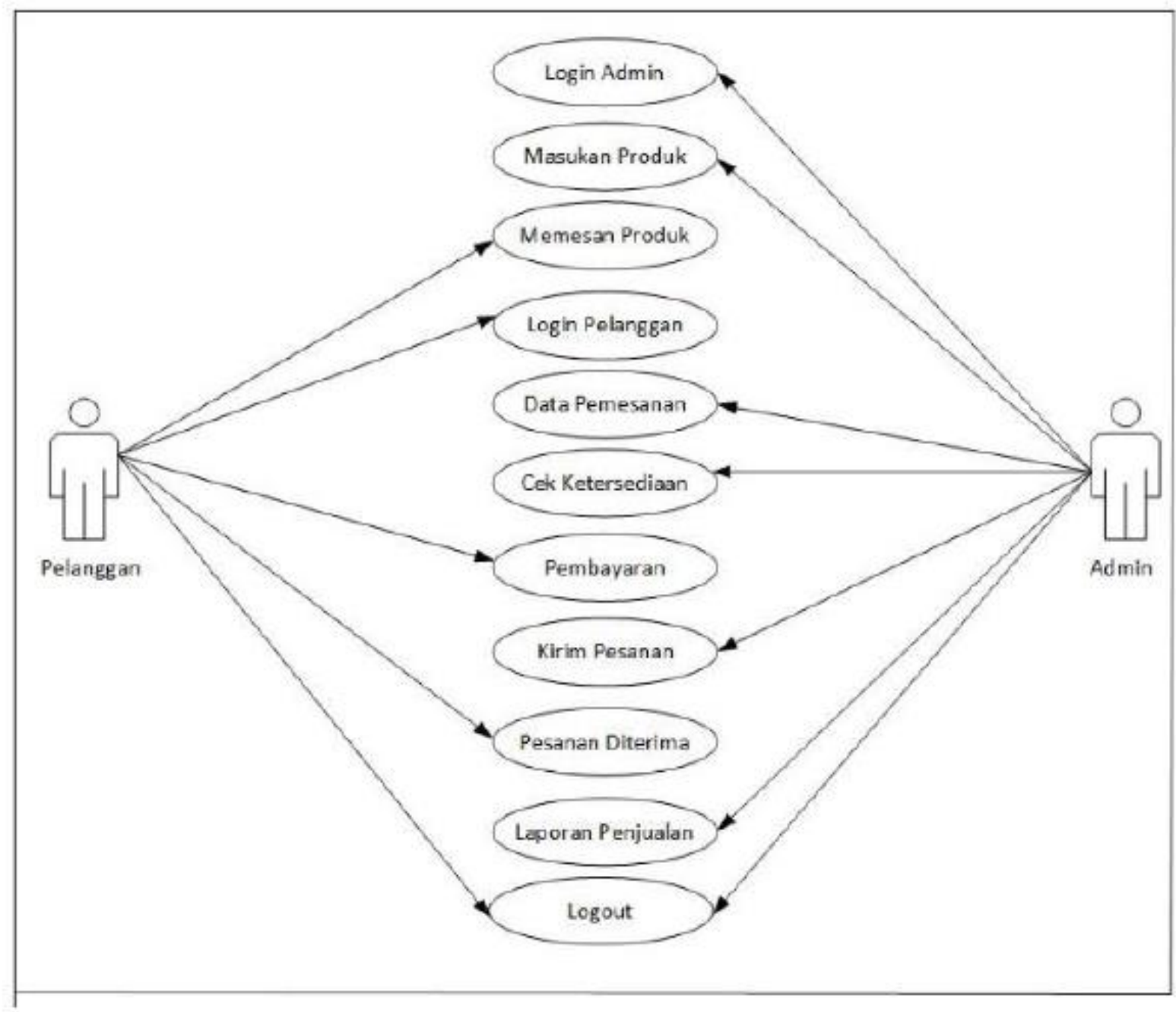

Gambar1 Use Case Diagram

2. Activity Diagram

Merupakan diagram lanjutan dari usecase yang digunakan untuk menggambarkan aktivitas yang terjadi dari setiap manu yang digunakan oleh pengguna dengan sistem, Aktivitas tersebut meliputi melihat, menambah, menghapus, mengedit, dan mencari, serta login dan logout.

a. Activity Diagram Login

Pengguna hanya perlu membuka sistem informasi penjualan batu kapur, sistem akan menampilkan form login. Pengguna diminta untuk memasukan username serta password yang telah dibuat, apabila proses validasi oleh sistem sukses dilakukan maka pengguna akan dibawa menuju ke halaman utama, sedangkan jika proses validasi gagal maka pengguna harus memasukan ulang username dan password yang valid. 


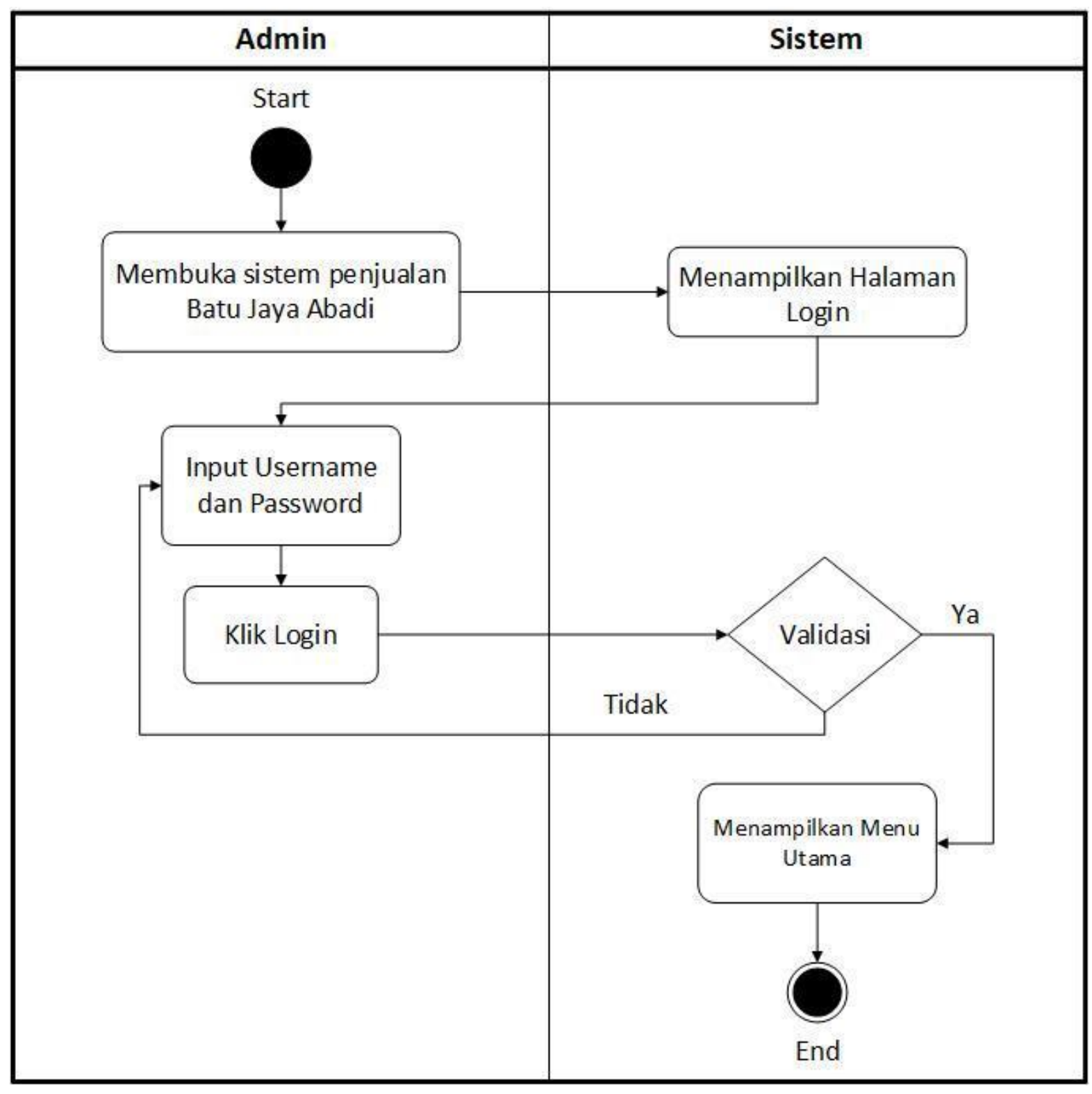

Gambar 2 Activity Diagram Login 
b. Activity Diagram Tambah Produk

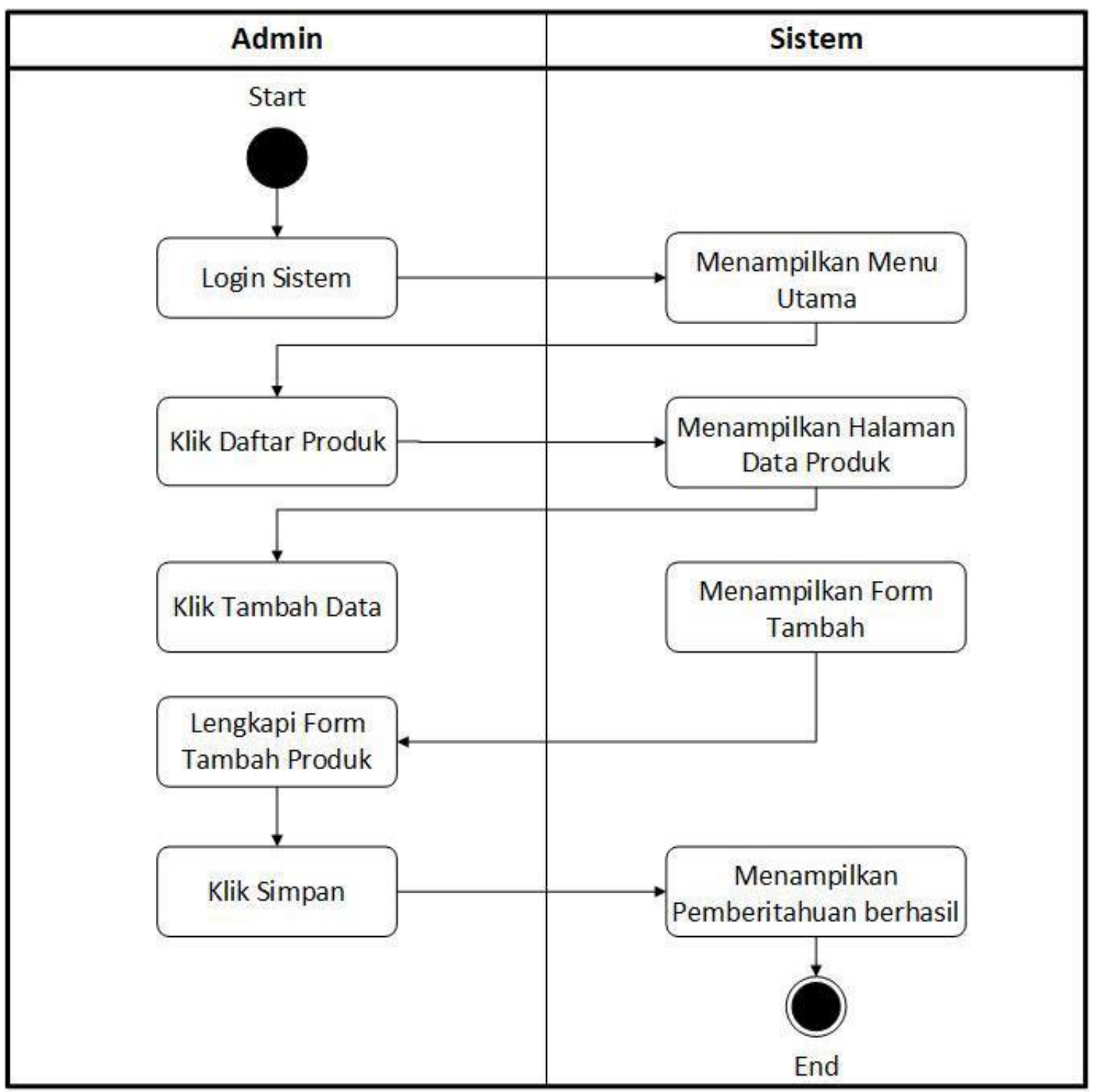

Gambar 3 Activity Diagram Tambah Produk

Diagram ini hanya berlaku bagi admin, karena admin dapat mengakses semua menu yang ada disistem. Setelah login ke dalam sistem, selanjutnya klik menu daftar produk dan sistem akan menampilkan halaman data produk. Selanjutnya untuk menambahkan data produk, maka pengguna harus mengisi form tambah produk dan klik simpan. Setelah proses tersebut dikerjakan maka sistem akan menampilkan pemberitahuan berhasil menambahkan produk yang baru.

c. Activity Diagram Daftar Produk Diagram ini juga hanya berlaku untuk admin. Halaman daftar produk ini hanya dapat dilihat oleh 
admin. Dalam halaman ini pengguna dapat melakukan fungsi edit dan hapus data produk yang sudah ada. Apabila pengguna klik edit, maka sistem akan menampilkan form untuk edit. Sedangkan apabila pengguna klik hapus, sistem akan hapus data produk.

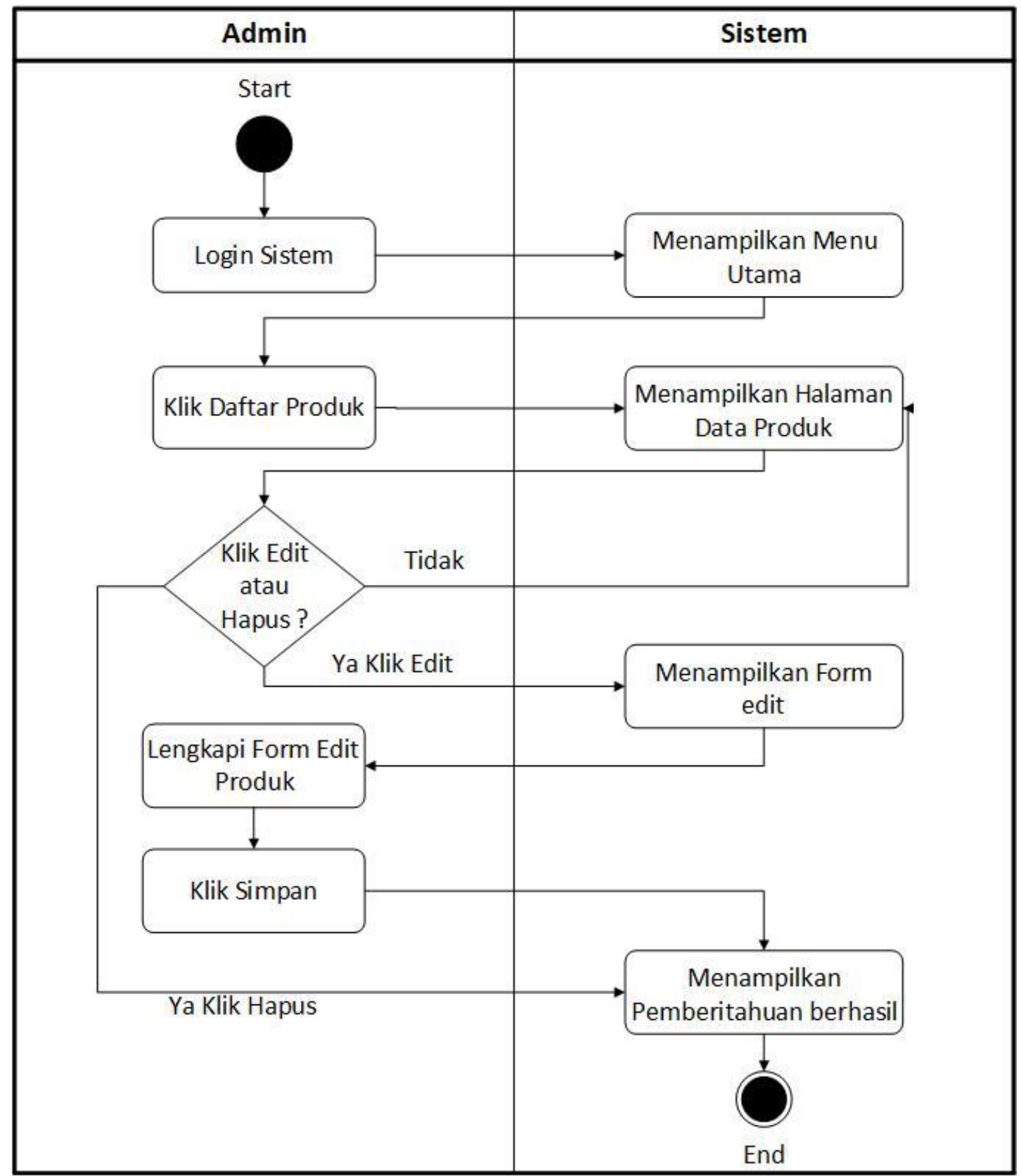

Gambar 4 Activity Diagram Daftar Produk 
d. Activity Diagram Tambah user Setelah login, pengguna lalu mengklik menu Daftar User maka sistem akan menampilkan halaman Data User. Pada halaman ini pengguna dapat melakukan tambah data user dan menampilkan form tambah user. Apabila pengguna mengisi form tambah dan klik tombol simpan. Selanjutnya sistem akan menampilkan pemberitahuan berhasil jika fungsi tersebut dilakukan.

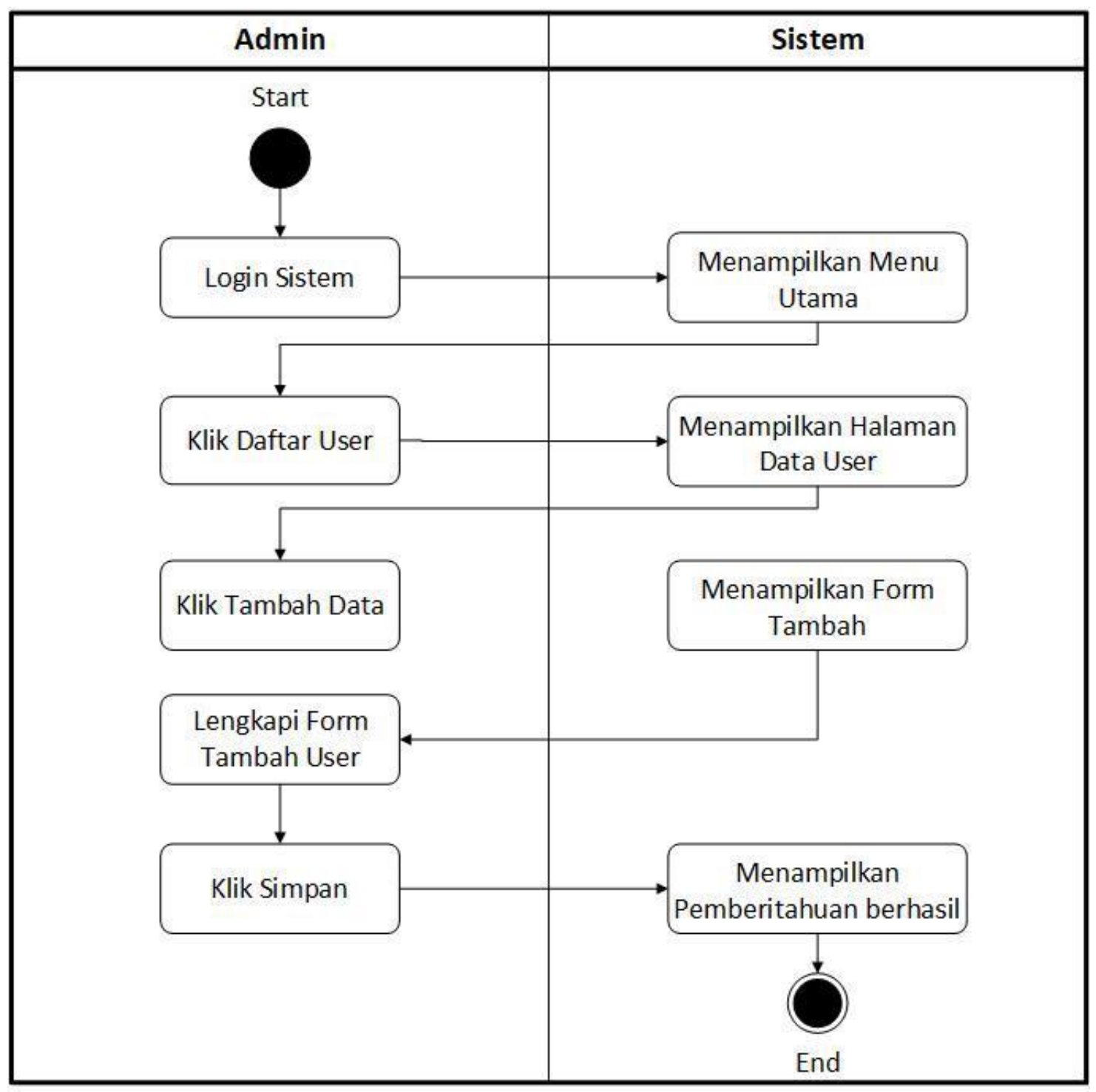

Gambar 5 Activity Diagram Tambah User 
e. Activity Diagram Tambah User

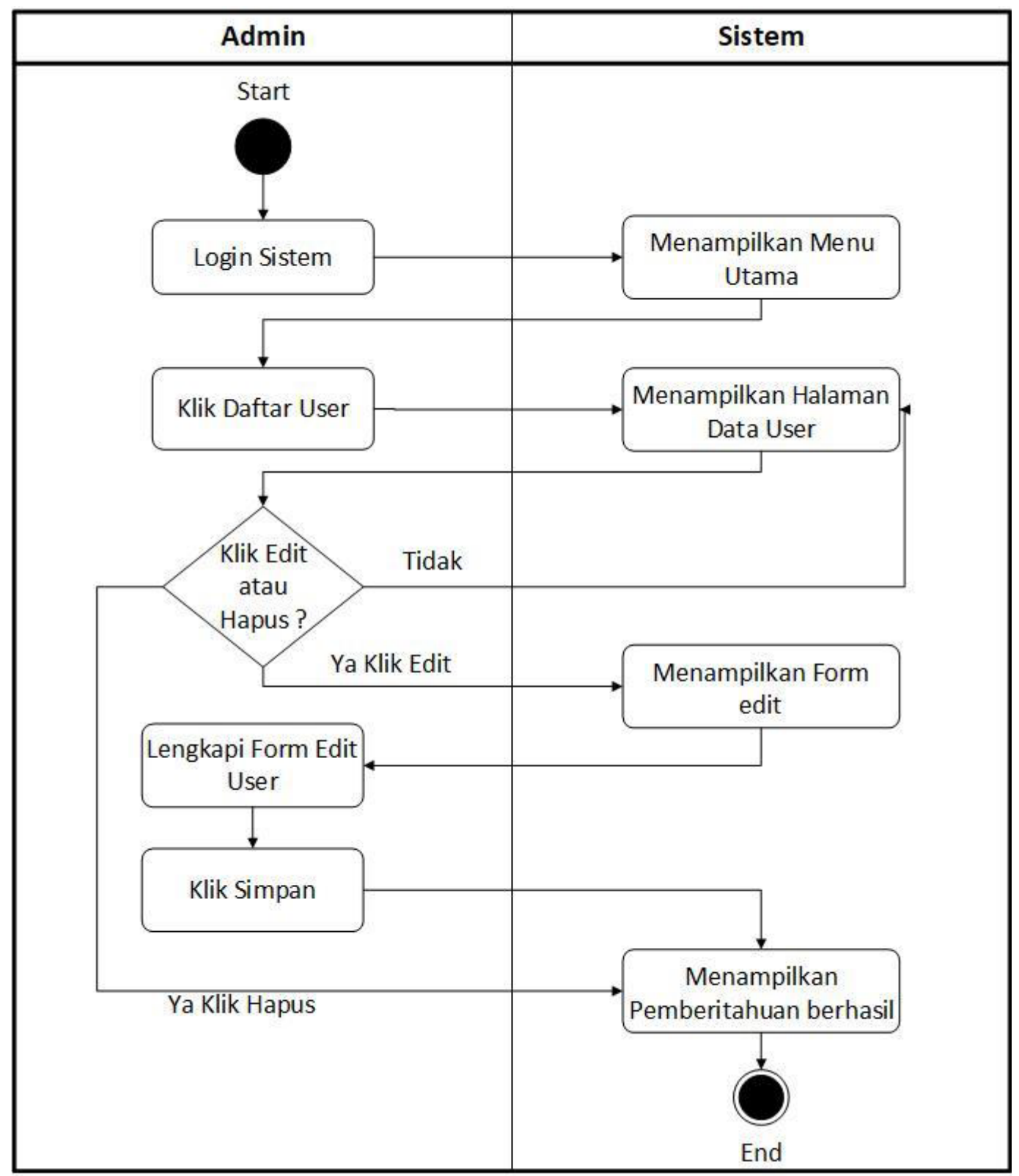

Gambar 6 Activity Diagram Tambah User

Pengguna lalu mengklik menu Daftar User maka sistem akan menampilkan halaman Data User. Pada halaman ini pengguna dapat melakukan fungsi edit dan hapus data user yang sudah ada.
Apabila pengguna klik edit, maka sistem akan menampilkan form edit. Sedangkan apabila pengguna klik hapus, sistem akan hapus data user. 
f. Activity Diagram Tambah Pelanggan

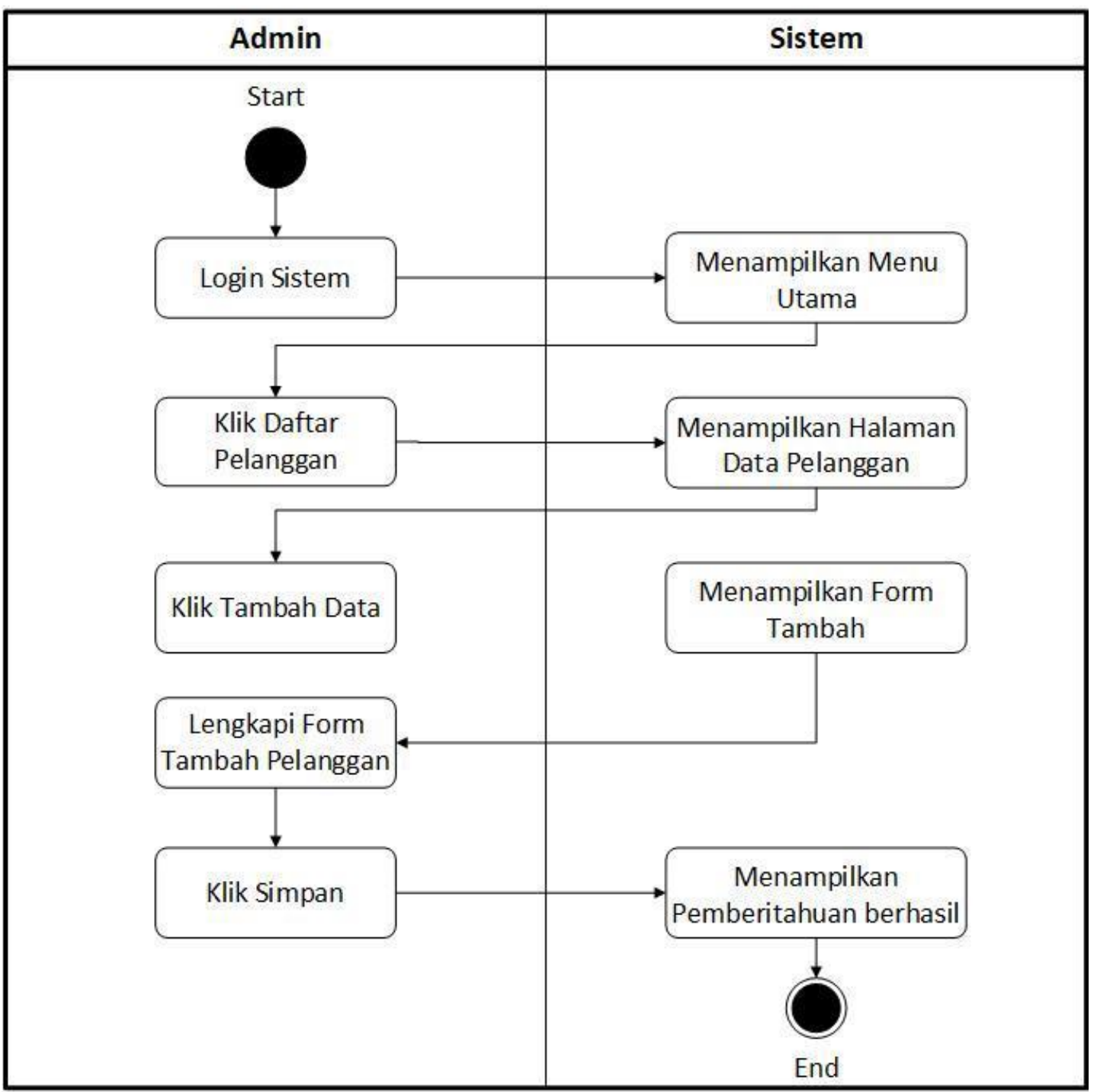

Gambar 7 Activity Diagram Tambah Pelanggan

Pengguna lalu mengklik menu Daftar Pelanggan maka sistem akan menampilkan halaman Data Pelanggan. Pada halaman ini pengguna dapat melakukan tambah data pelanggan dan menampilkan form tambah pelanggan. Apabila pengguna mengisi form tambah dan klik tombol simpan. Selanjutnya sistem akan menampilkan pemberitahuan berhasil jika fungsi tersebut dilakukan.

g. Activity Diagram Daftar Pelanggan Daftar User maka sistem akan menampilkan halaman Daftar Pelanggan. Pada halaman ini pengguna dapat melakukan fungsi edit dan hapus data pelanggan yang sudah ada. Apabila pengguna klik edit, maka sistem akan 
menampilkan form edit. Sedangkan apabila pengguna klik hapus, sistem akan hapus data pelanggan. Selanjutnya sistem akan menampilkan pemberitahuan berhasil apabila salah satu fungsi tersebut dilakukan.

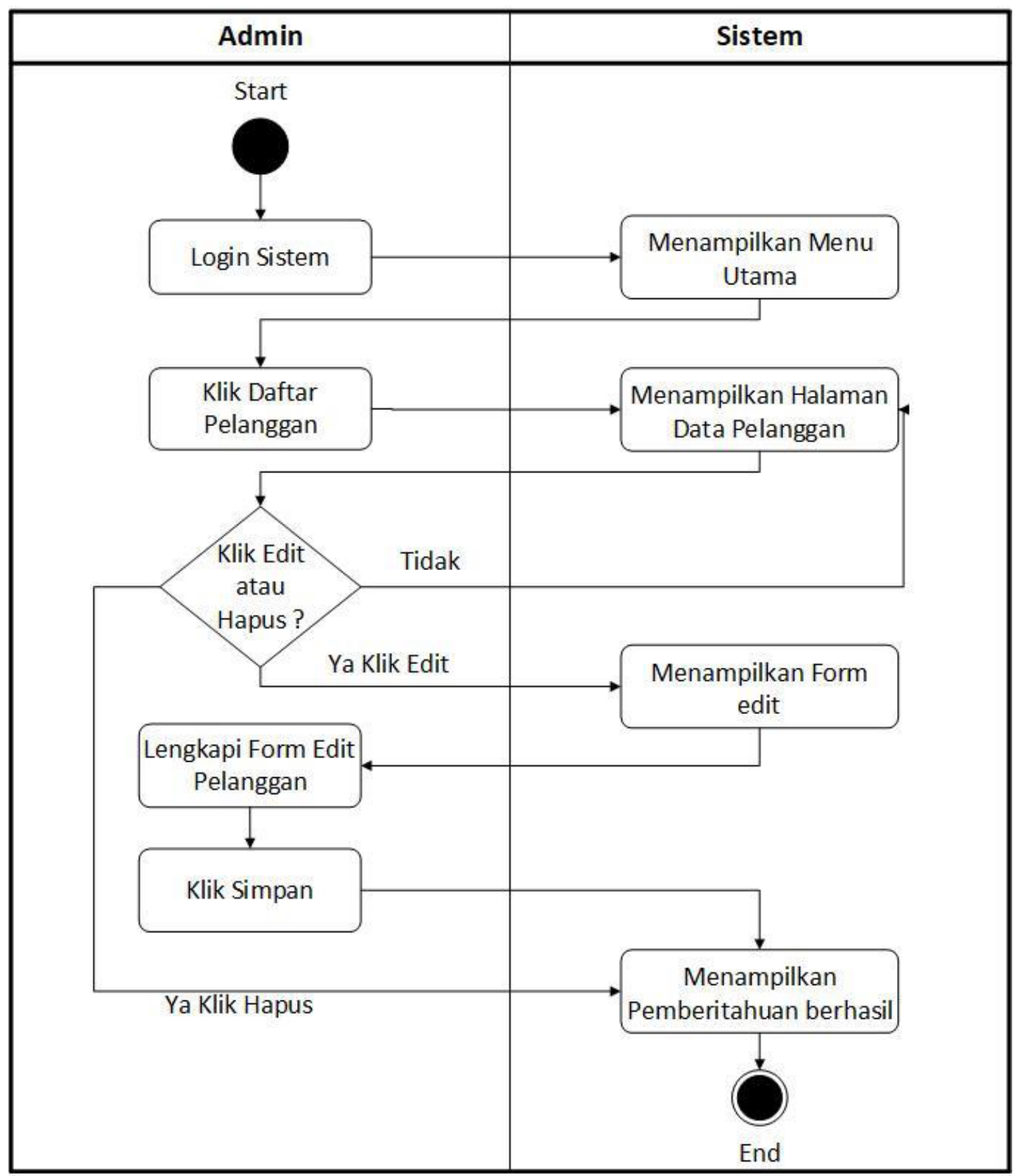

Gambar 8 Activity Diagram Daftar Pelanggan 
h. Activity Diagram profil user

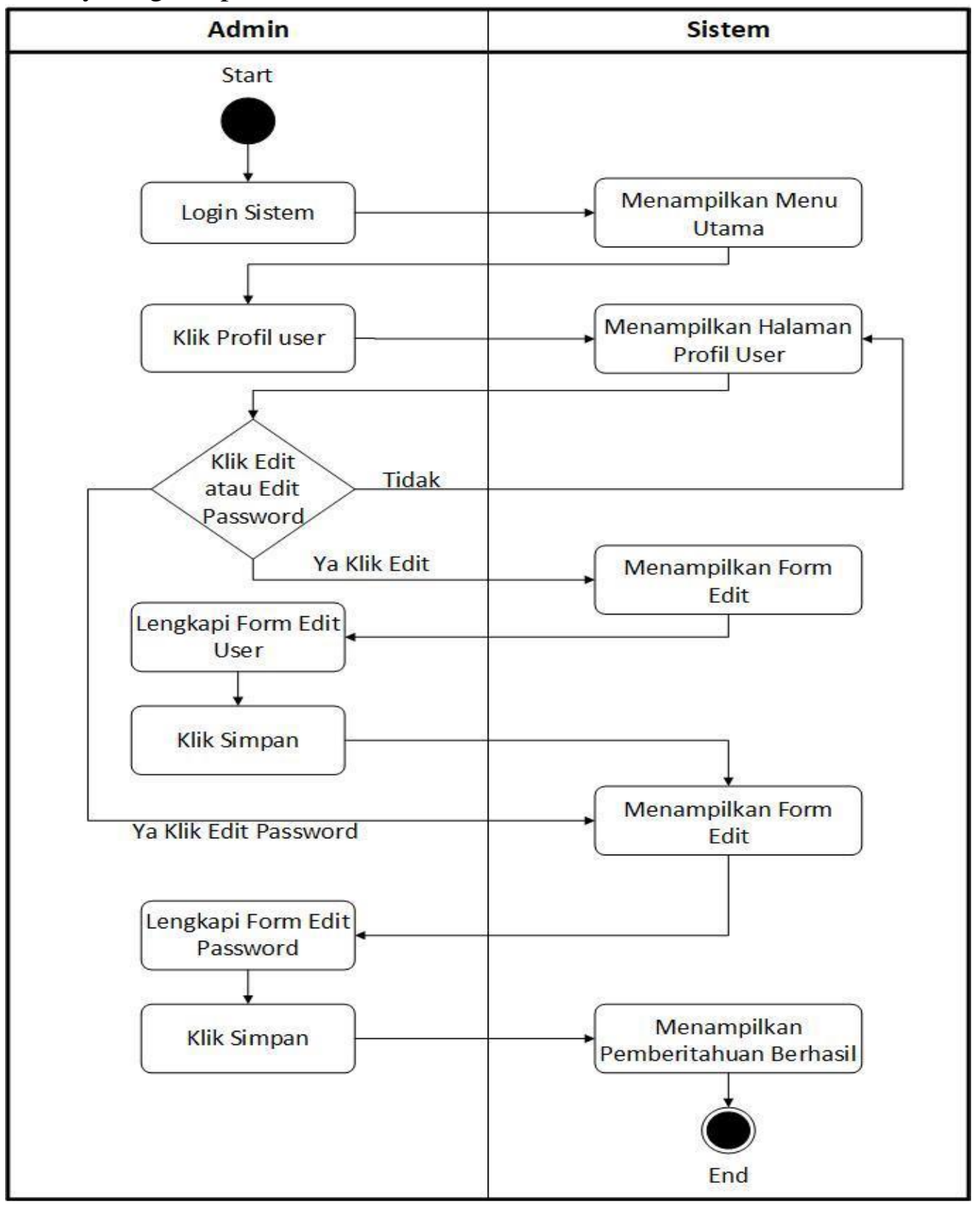

Gambar 8 Activity Diagram profile User

Dalam halaman ini, pengguna dilengkapi dengan fungsi edit data pribadi dan ubah password. Seperti halnya diagram yang ada, akhir dari

i. Activity Diagram Logout

Dalam proses logout ini, pengguna mengklik tombol yang bertuliskan prosedur ini adalah pemberitahuan perubahan berhasil apabila salah satu fungsi tersebut dilakukan.

logout pada sistem yang terletak pada pojok kanan atas sistem, lalu klik logout. 


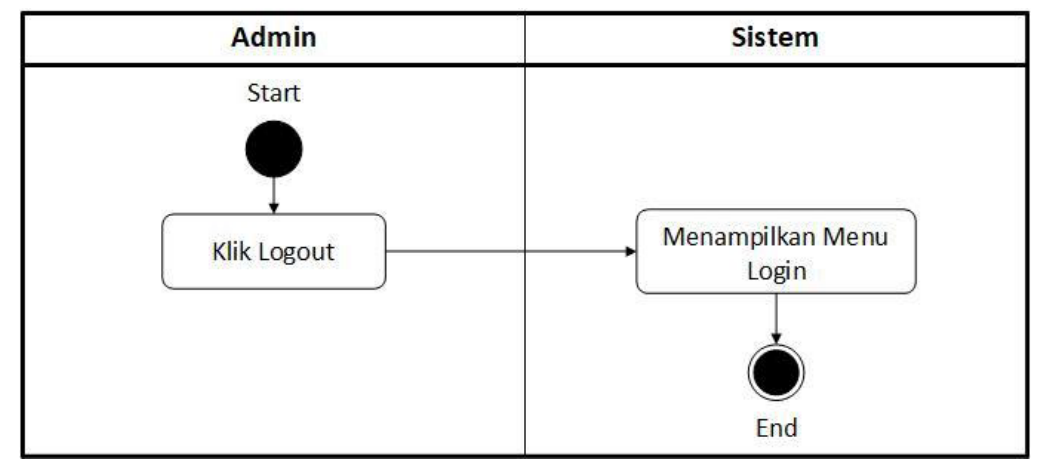

Gambar 8 Activity Diagram Logout

j. Activity Diagram login pelanggan

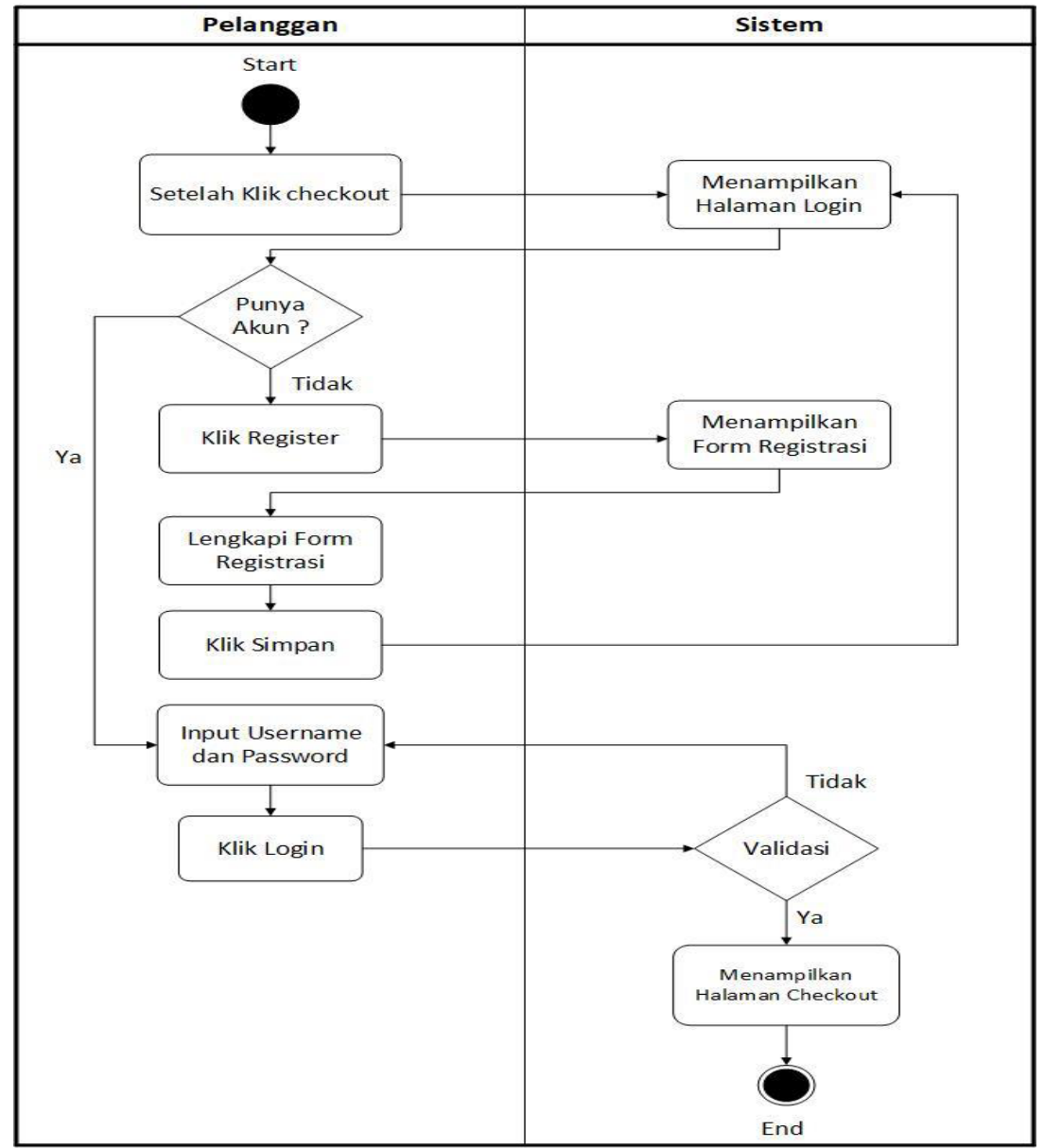

Gambar 9 Activity Diagram Login Pelanggan

Setelah pelanggan memesan produk yang dibeli dan klik tombol checkout maka sistem akan meminta login terlebih dahulu dan menampilkan form login. Pelanggan diminta untuk memasukan email serta password yang valid, apabila proses validasi oleh sistem sukses dilakukan maka pengguna akan dibawa menuju ke halaman utama, sedangkan jika 
proses validasi gagal maka pengguna harus memasukan ulang email dan password yang valid. Jika pelanggan tidak mempunyai akun maka pelanggan harus melakukan registrasi terlebih dahulu.

k. Activity Diagram pembelian produk

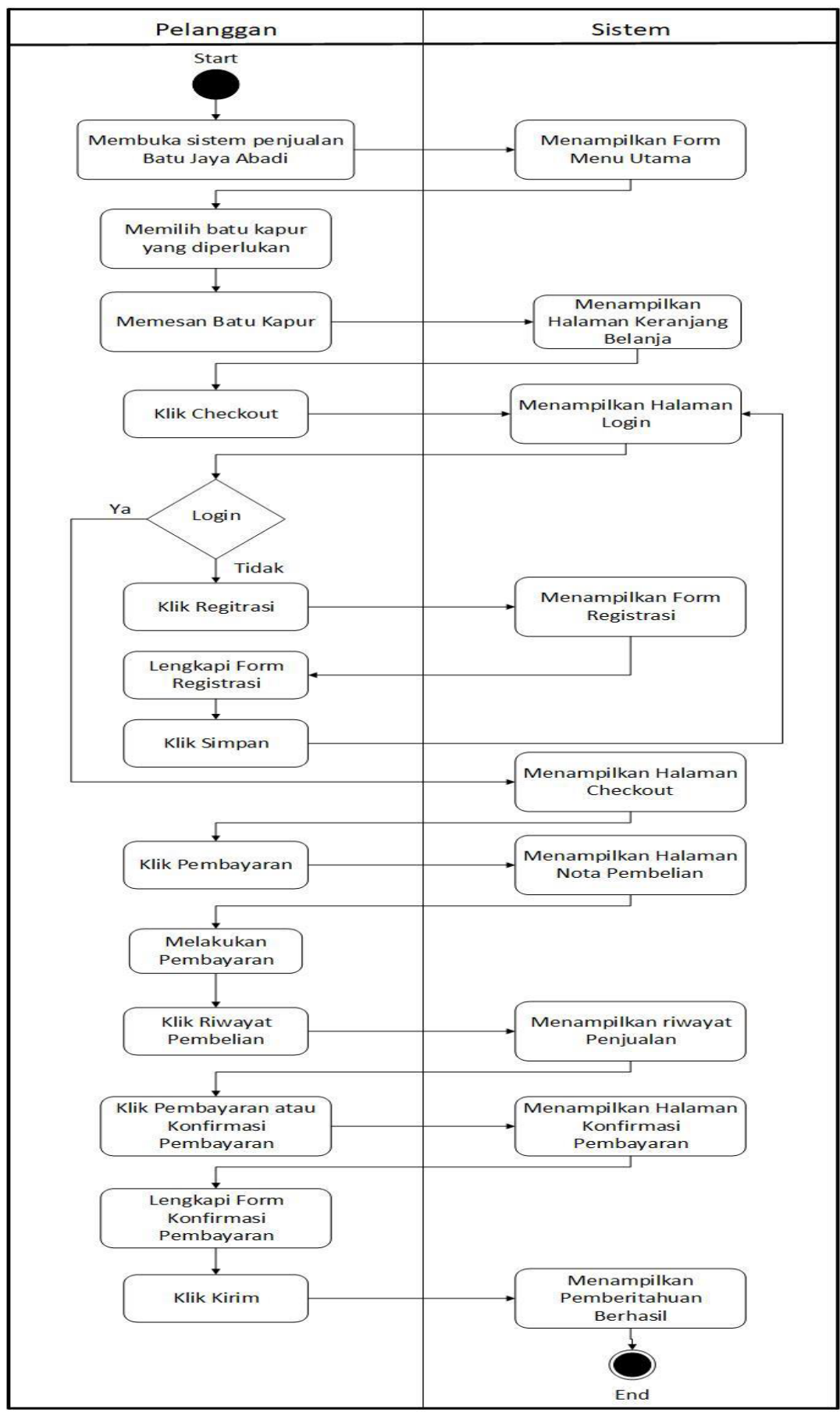

Gambar 10 Activity Diagram Pembelian Produk 
Dalam proses ini pelanggan membuka sistem penjualan batu kapur dan akan menuju halaman menu utama pelanggan. Pelanggan memilih batu kapur yang ingin dibeli dan masuk kehalaman keranjang. Setelah itu klik checkout makan pelanggan wajib login terlebih dahulu. Setelah login pelanggan akan diarahkan ke halaman checkout untuk mengetahui berapa yang harus dibayar. Klik pembayaran untuk melihat nota pembelian yang pelanggan beli. Setalah itu pelanggan membuka riwayat belanja untuk melakukan konfirmasi pembayaran dengan mengklik tombol pembayaran yang ada di halaman riwayat belanja.

\section{Sequence Diagram}

a. Sequence Diagram Login

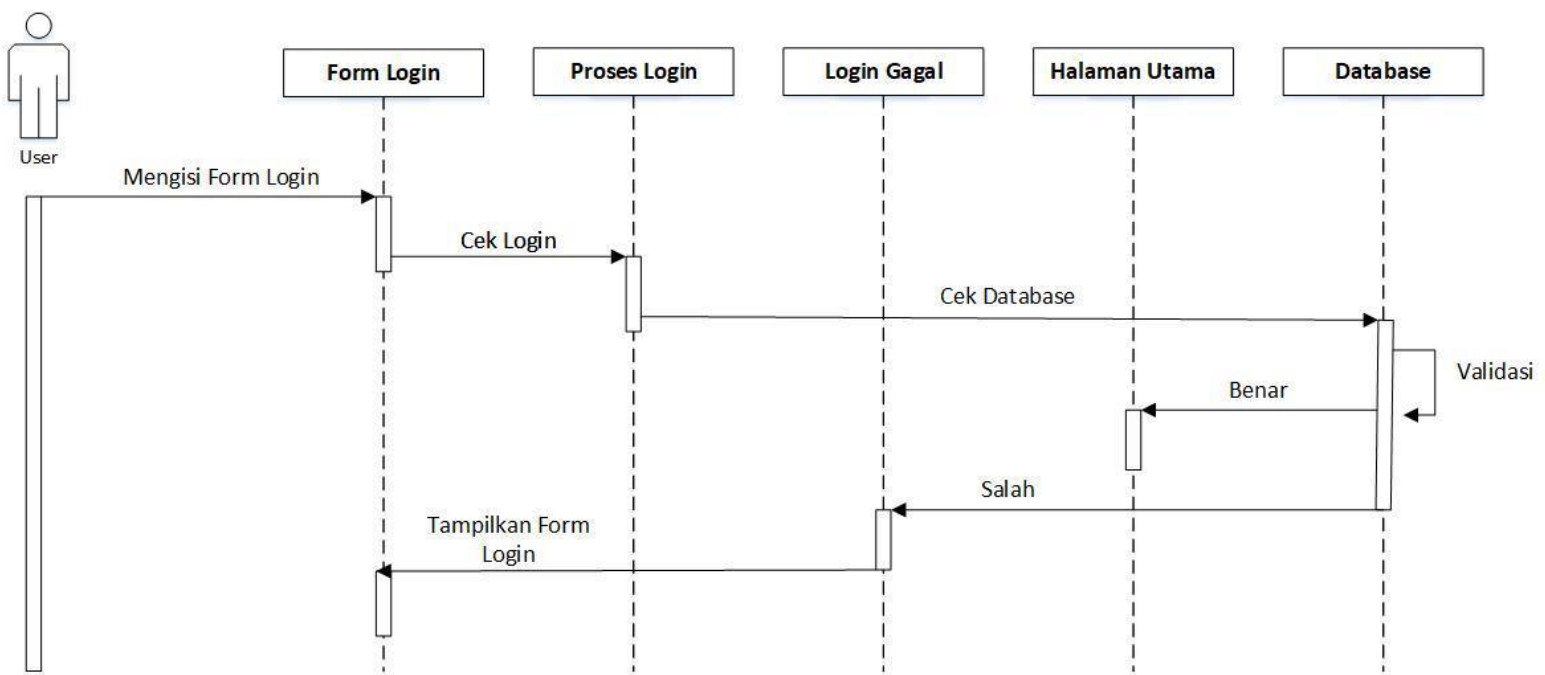

Gambar 11 Sequence Diagram Login

Setelah mengisikan form login pada halaman awal, selanjutnya sistem akan mengecek data tersebut valid atau tidak sebagai user sistem pada database. Jika valid, maka halaman akan diarahkan ke halaman menu utama, tetapi jika tidak valid maka sistem akan mngembalikan ke halaman login dengan memberikan pesan kesalahan, selanjutnya pengguna harus mengisikan kembali form login dengan benar. b. Sequence Diagram Tambah Data Sequence diagram diatas berlaku untuk semua proses yang melakukan tambah data, seperti tambah produk, tambah user, dan tambah pelanggan. Setelah form tambah data muncul, pengguna mengisi kolom tersebut, selanjutnya sistem akan memproses data isian tadi apakah sudah sesuai atau belum. Jika sudah sesuai maka proses penyimpanan data ke database, jika belum maka pengguna harus melengkapinya terlebih dahulu. Jika sudah disimpan, data akan langsung ditampilkan oleh sistem. 


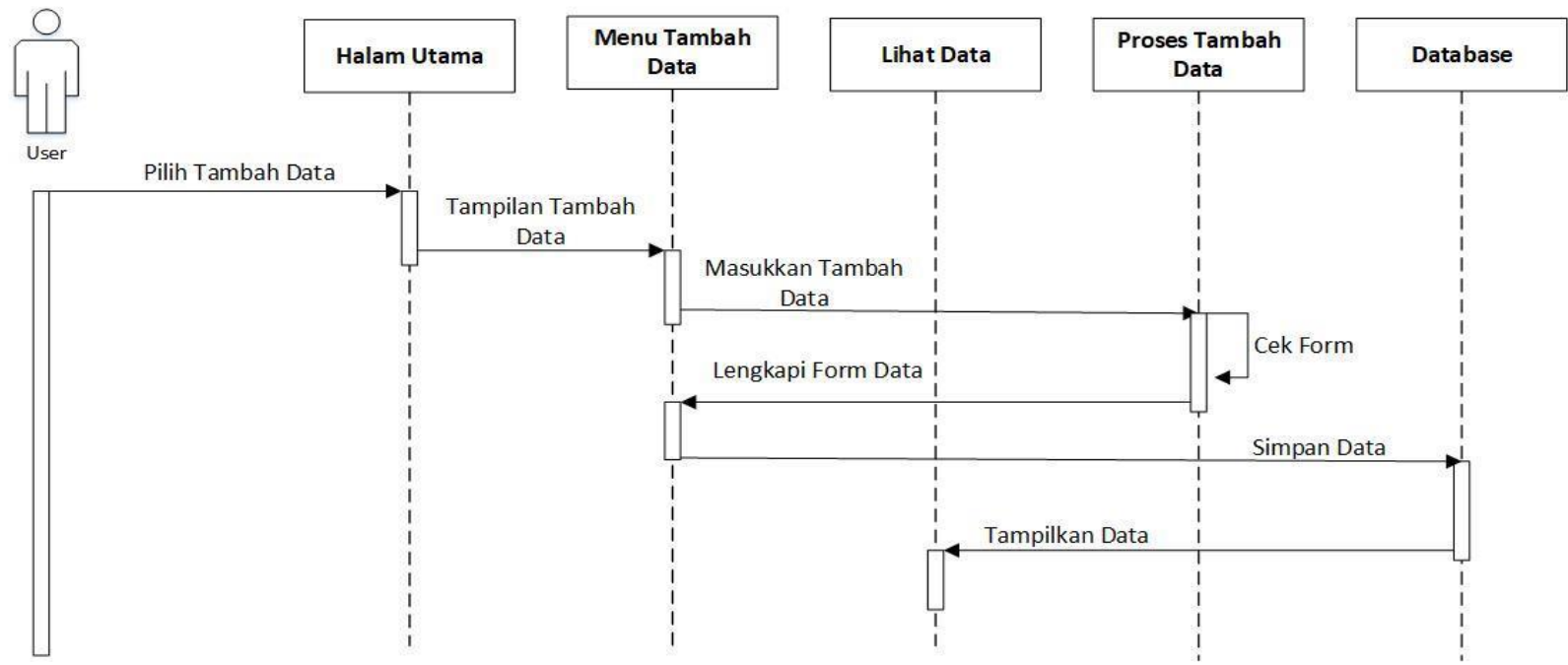

Gambar 12 Sequence Diagram Tambah Data

\section{c. Sequence Diagram Edit Data}

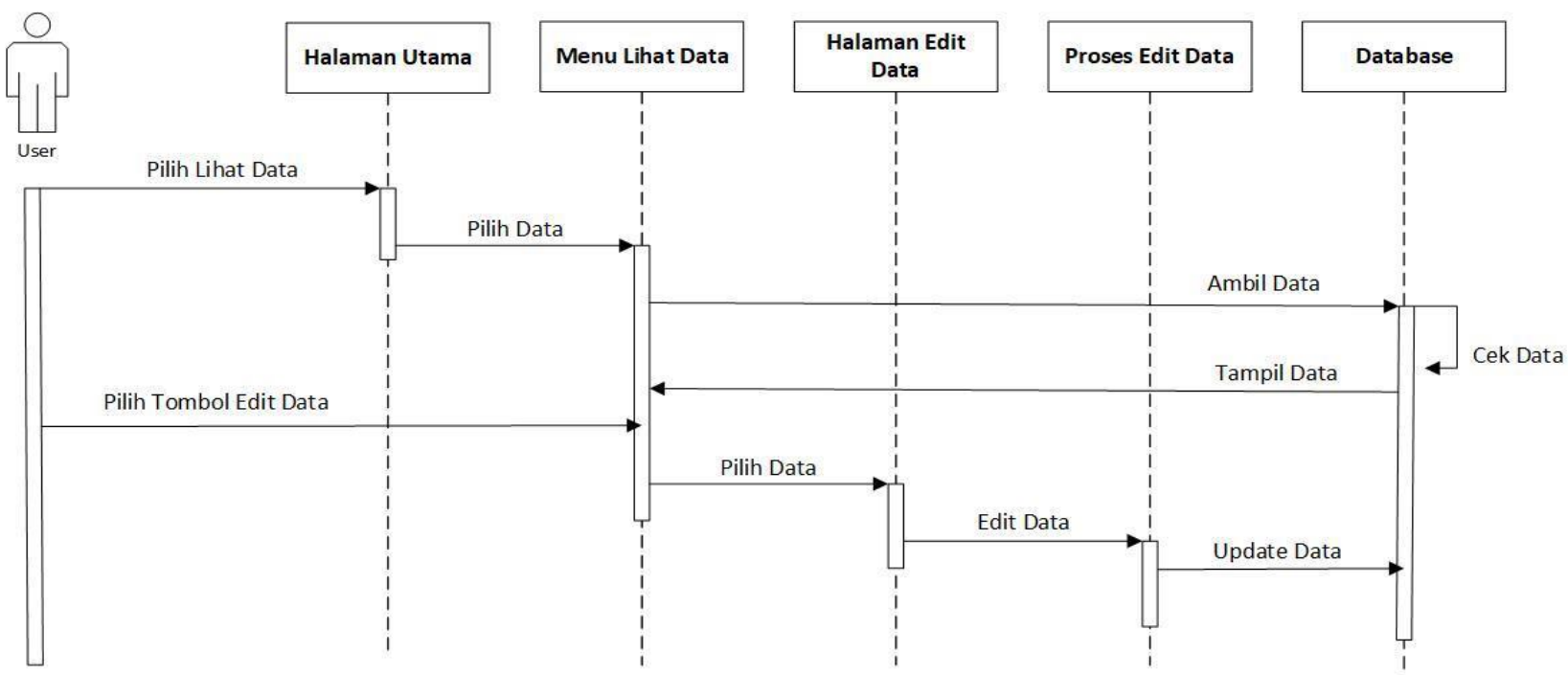

Gambar 13. Sequence Diagram Edit Data

Secara ringkas proses yang terjadi diatas adalah apabila pengguna memilih edit data maka sistem akan menampilkan form edit data, selanjutnya pilih data apa saja yang akan di edit dan klik simpan. Proses selanjutnya sistem akan melakukan perubahan pada data tersebut didalam database.

\section{d. Sequence Diagram Lihat Data}

Pilih data mana yang akan dilihat, sistem akan mengambil data dari database dan mengembalikannya kembali ke halaman tersebut. 


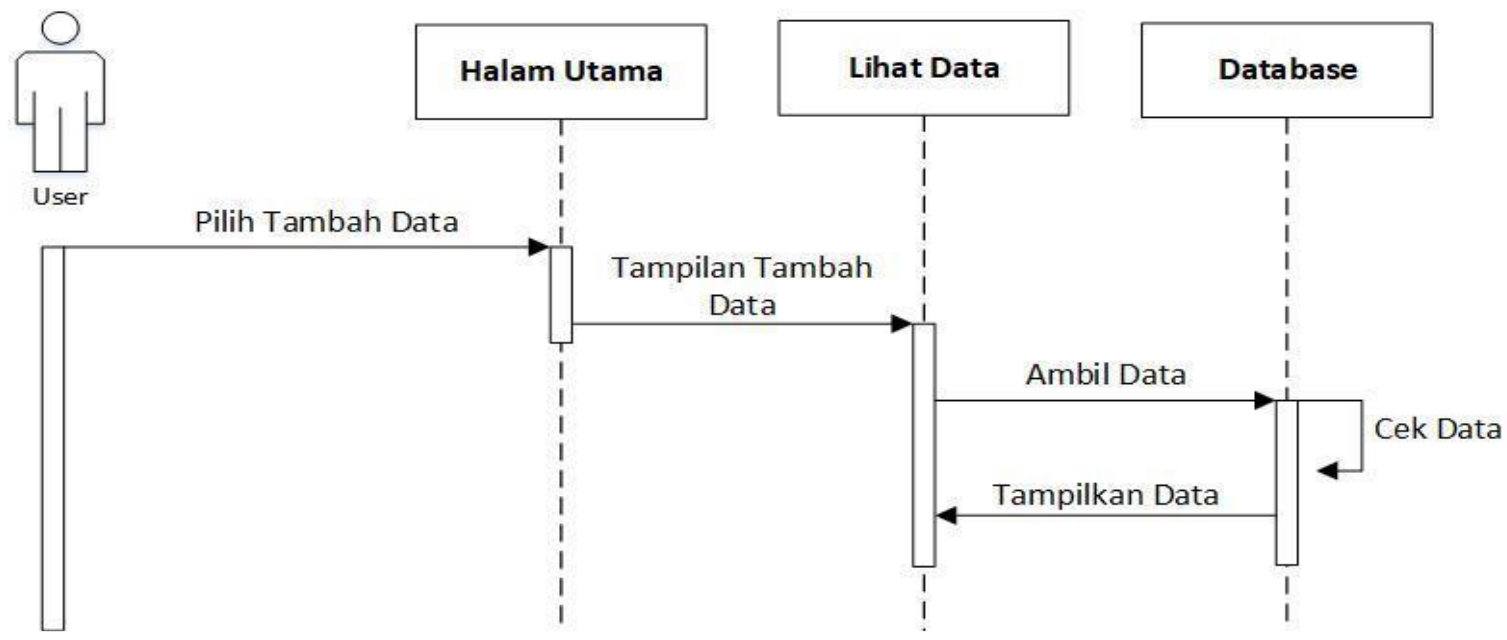

Gambar 14. Sequence Diagram Lihat Data

e. Sequence Diagram Hapus Data Setelah pengguna memilih data mana yang akan dihapus, database akan melakukan penggecekan data tersebut dan melakukan penghapusan terhadap data.
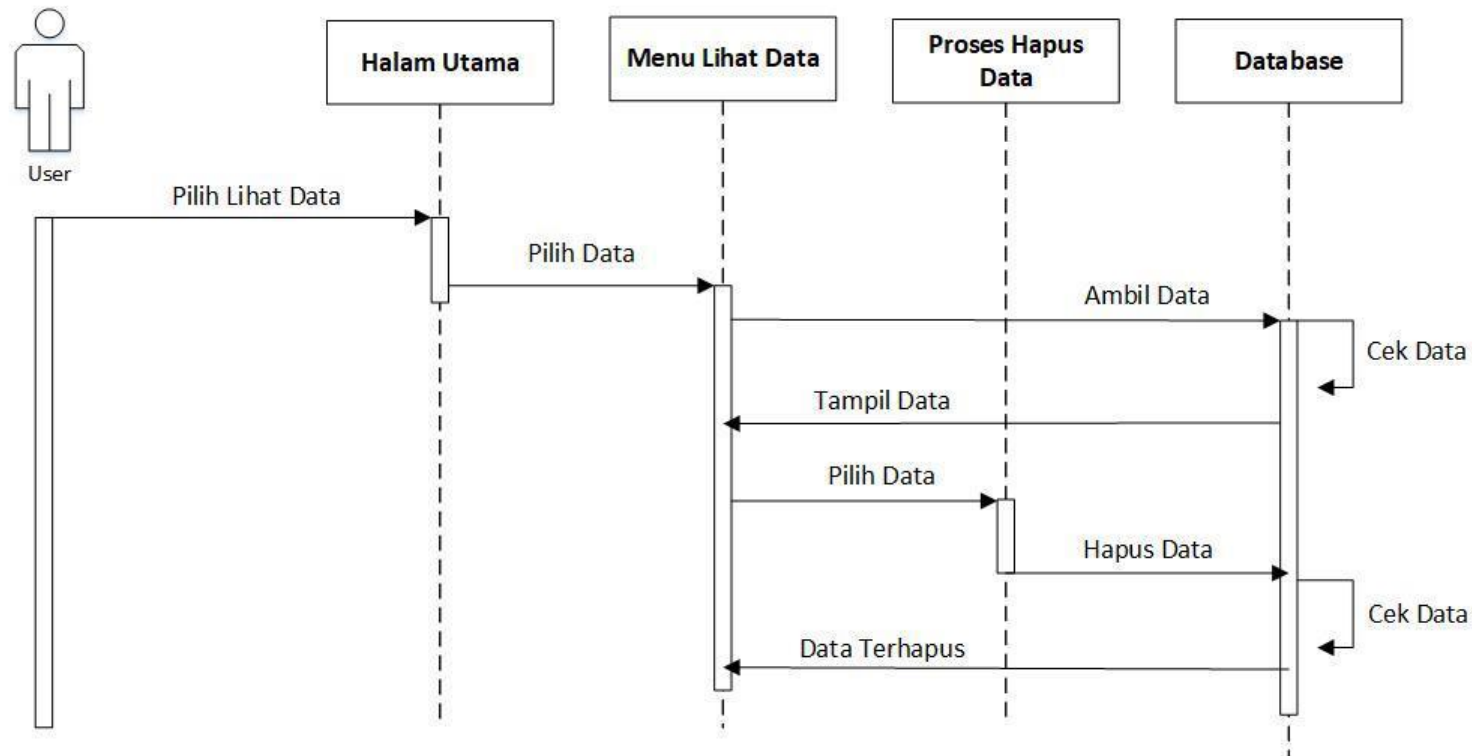

Gambar 15. Sequence Diagram Hapus Data

f. Sequence Diagram Cari Data

Proses pencarian data hanya dapat dilakukan pada menu - menu tertentu saja. Setelah masuk halaman tersebut, pengguna dapat melakukan pencarian data. 


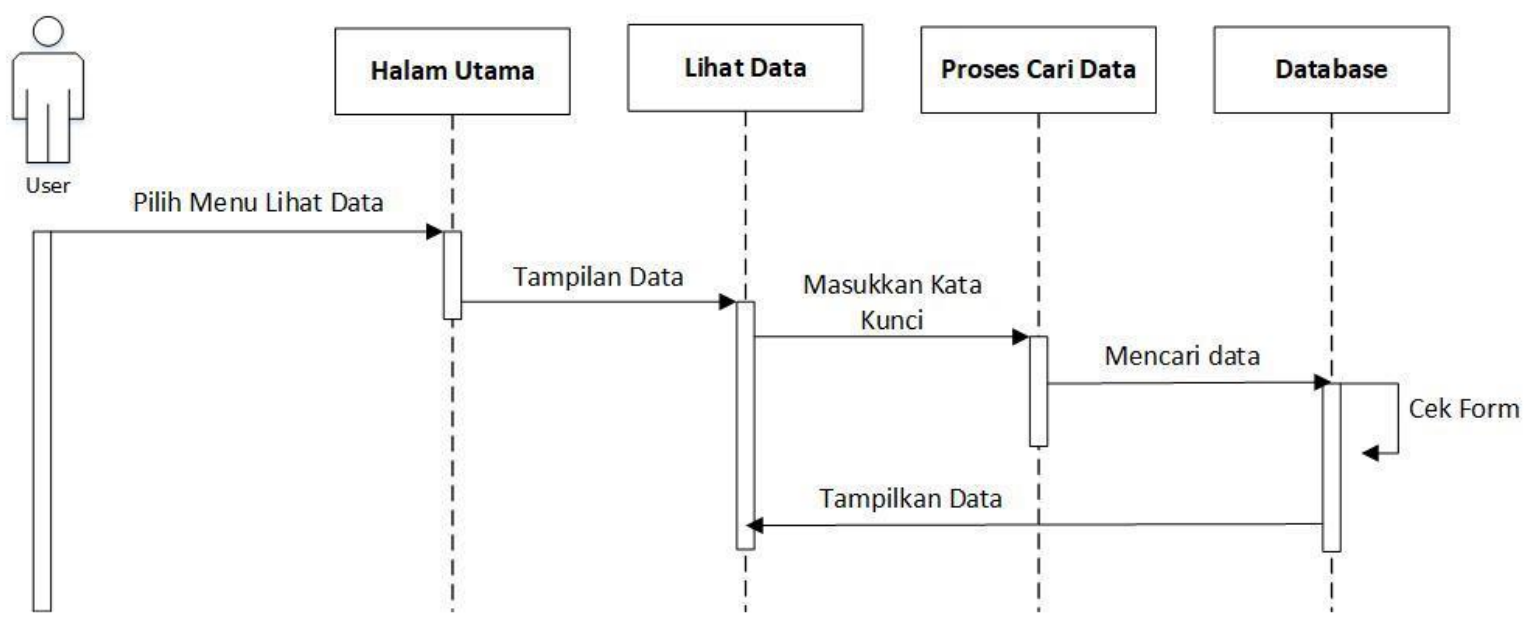

Gambar 16. Sequence Diagram Cari Data

g. Sequence Diagram Laporan

Pilih data penjualan yang mana yang akan dilihat atau dicetak laporan penjualannya. Sistem akan mengambil data tersebut dan menampilkannya dari database. Selanjutnya pilih cetak, sistem akan membuat berkas laporan dalam bentuk pdf.
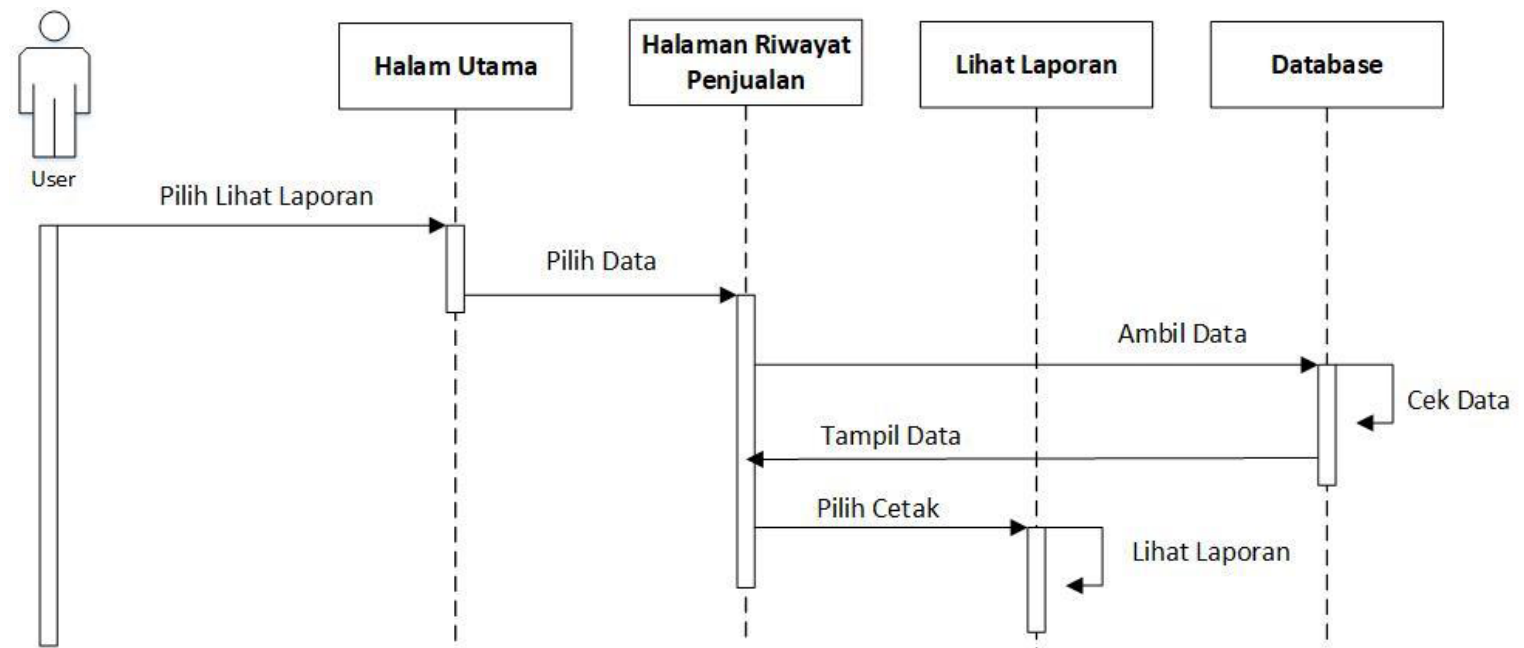

Gambar 17. Sequence Diagram Laporan

\section{Metode Pengembangan Sistem}

Pada penelitian ini, Penulis menggunakan metode waterfall dalam mengembangkan aplikasi system informasi penjualan batu kapur berbasis web. Berikut adalah proses pemodelan menggunakan waterfall dalam pembuatan aplikasi ini :
a. Analisis

Analisis masalah adalah langkah awal dari analisis sistem. Langkah ini diperlukan untuk mengetahui permasalahan apa saja yang terjadi pada sistem yang telah berjalan. Analisa masalah yang dimaksud di sini adalah informasi penjualan batu kapur menggunakan buku seperti data-data penjualan dianggap masih kurang 
maksimal, pembuatan laporan yang menggunakan MS. Excel dengan cara mengetik data-data penjualan, Tidak adanya konfirmasi pembayaran dari pelanggan ke penjual dan konfirmasi penerimaan dana dari penjual ke pelanggan, Kurang cepatnya pelayanan terhadap pelanggan, Selain itu juga pelanggan tidak mengetahui ketersediaan batu kapur yang ingin dibeli.

\section{b. Desain}

Membuat rancangan program aplikasi system informasi penjualan batu kapur pada CV. XYZ berbasis website, sesuai dengan data yang dibutuhkan oleh perusahaan.

\section{c. Pengodean}

Membuat program dengan menggunakan bahasa pemrograman yang berbasis website yaitu PHP dan MySQL sebagai database.

\section{d. Pengujian}

Pada tahapan pengujian atau implementasi ini memperbaiki bug yang masih error, sehingga aplikasi sesuai dengan yang dibutuhkan oleh perusahaan.

\section{e. Pemeliharaan}

pada tahapan ini dilakukan maintenance dan backup data pada aplikasi Sistem Informasi Penjualan Batu kapur berbasis website.

\section{Perancangan Sistem dan Implementasi}

1. Tampilan Login Admin

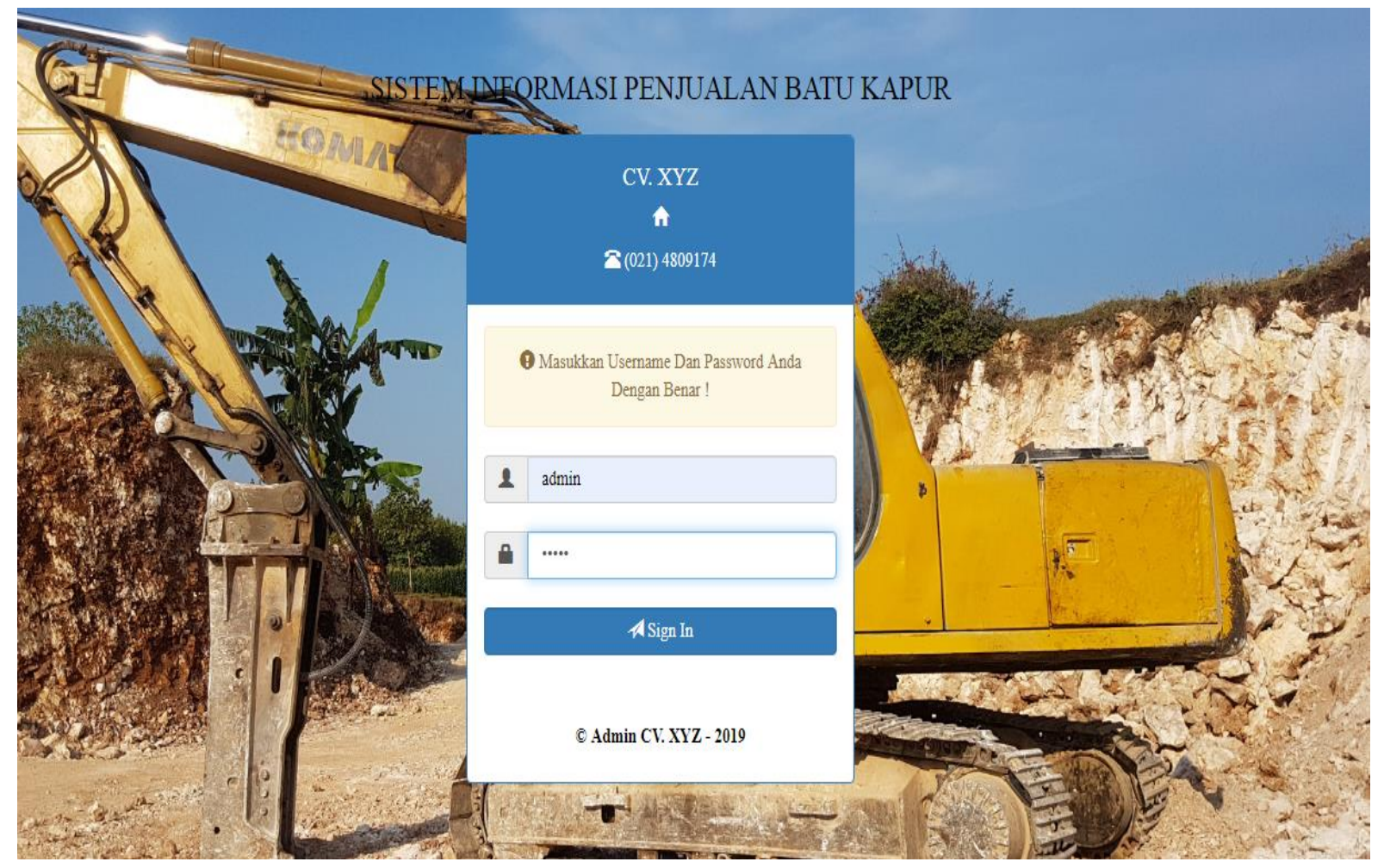

Gambar 18. Tampilan Login Admin 


\section{Tampilan dashboard Admin}

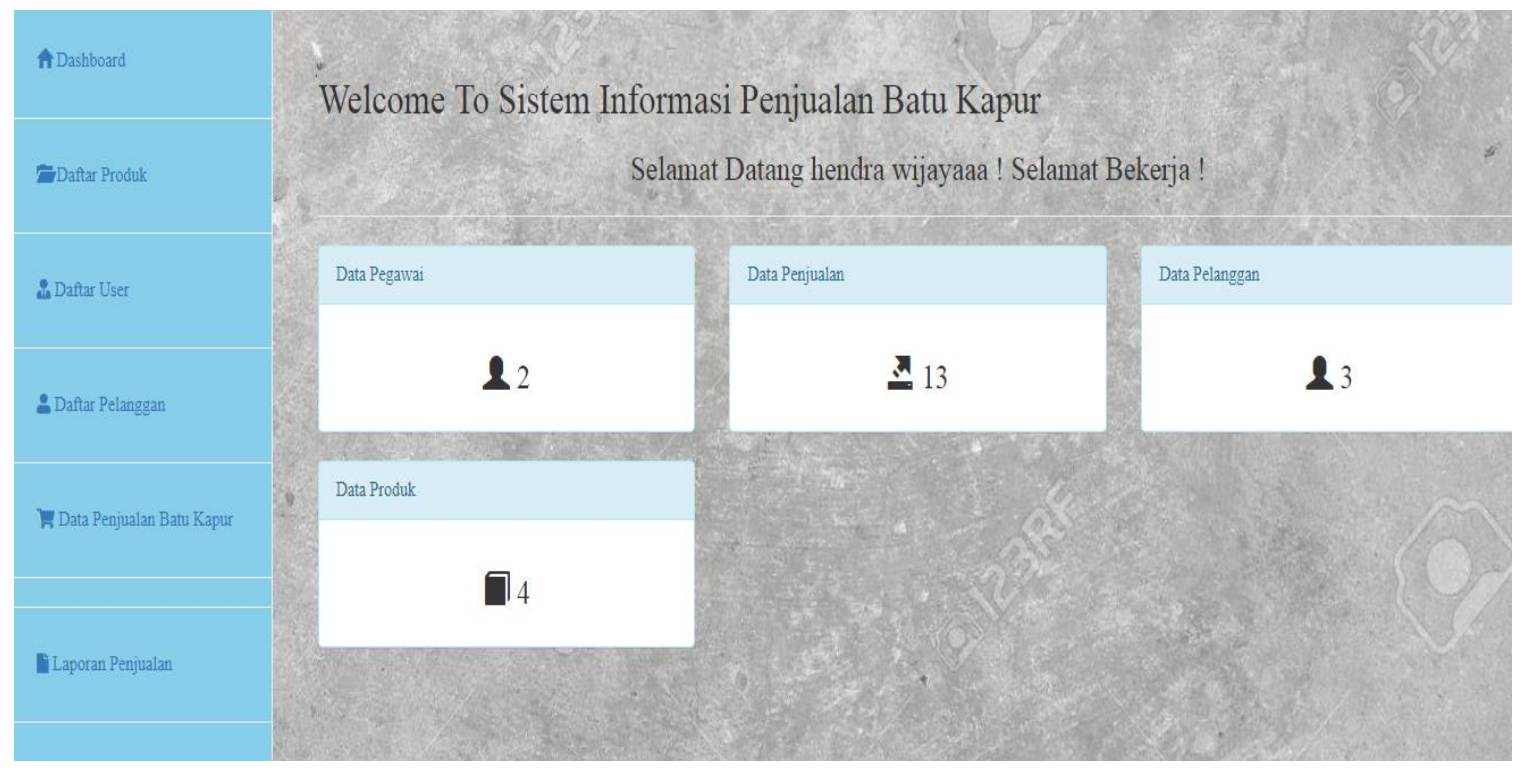

Gambar 19. Tampilan Dashboard Admin

\section{Tampilan Daftar Produk}

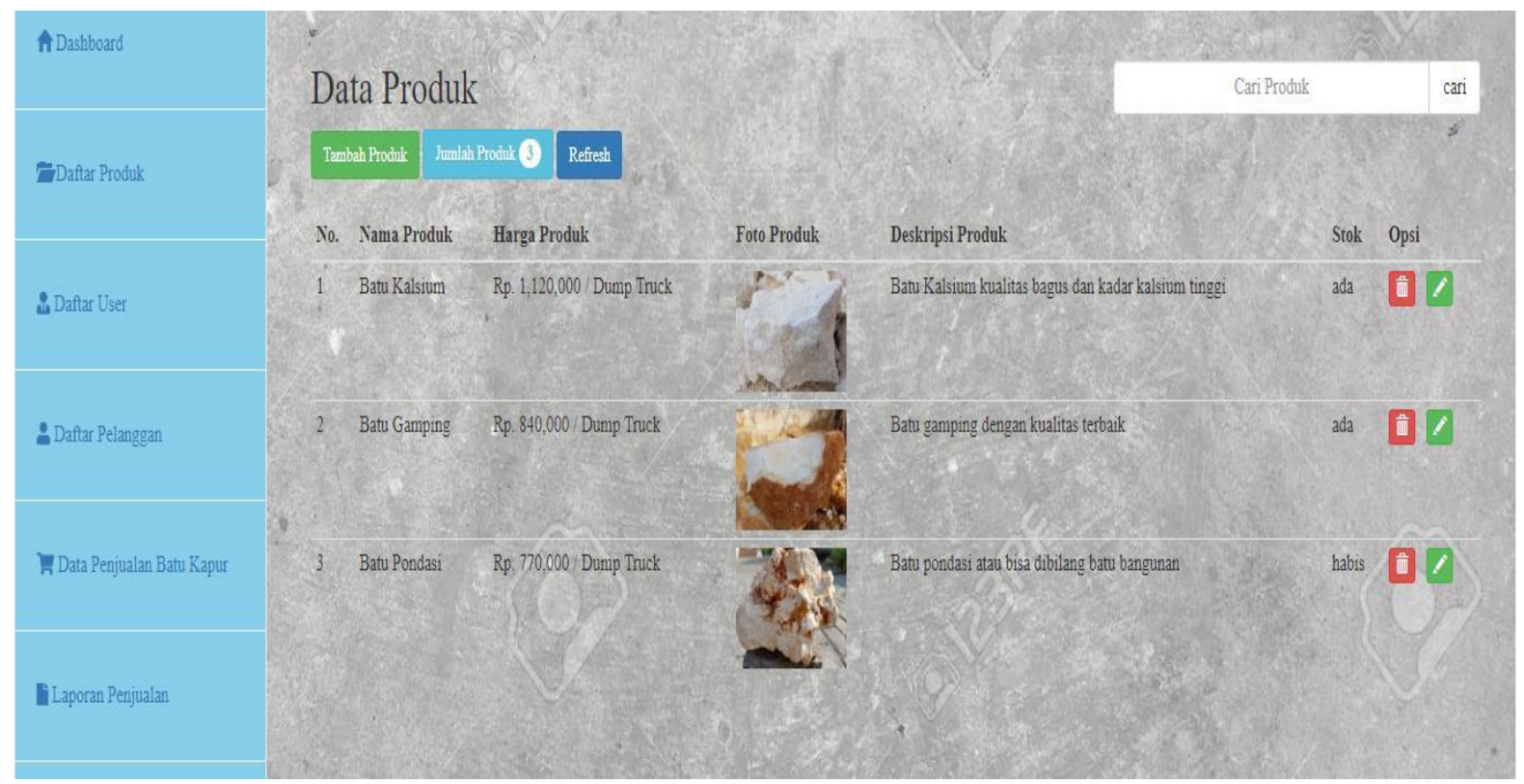

Gambar 19. Tampilan Daftar Produk 
4. Tampilan tambah produk

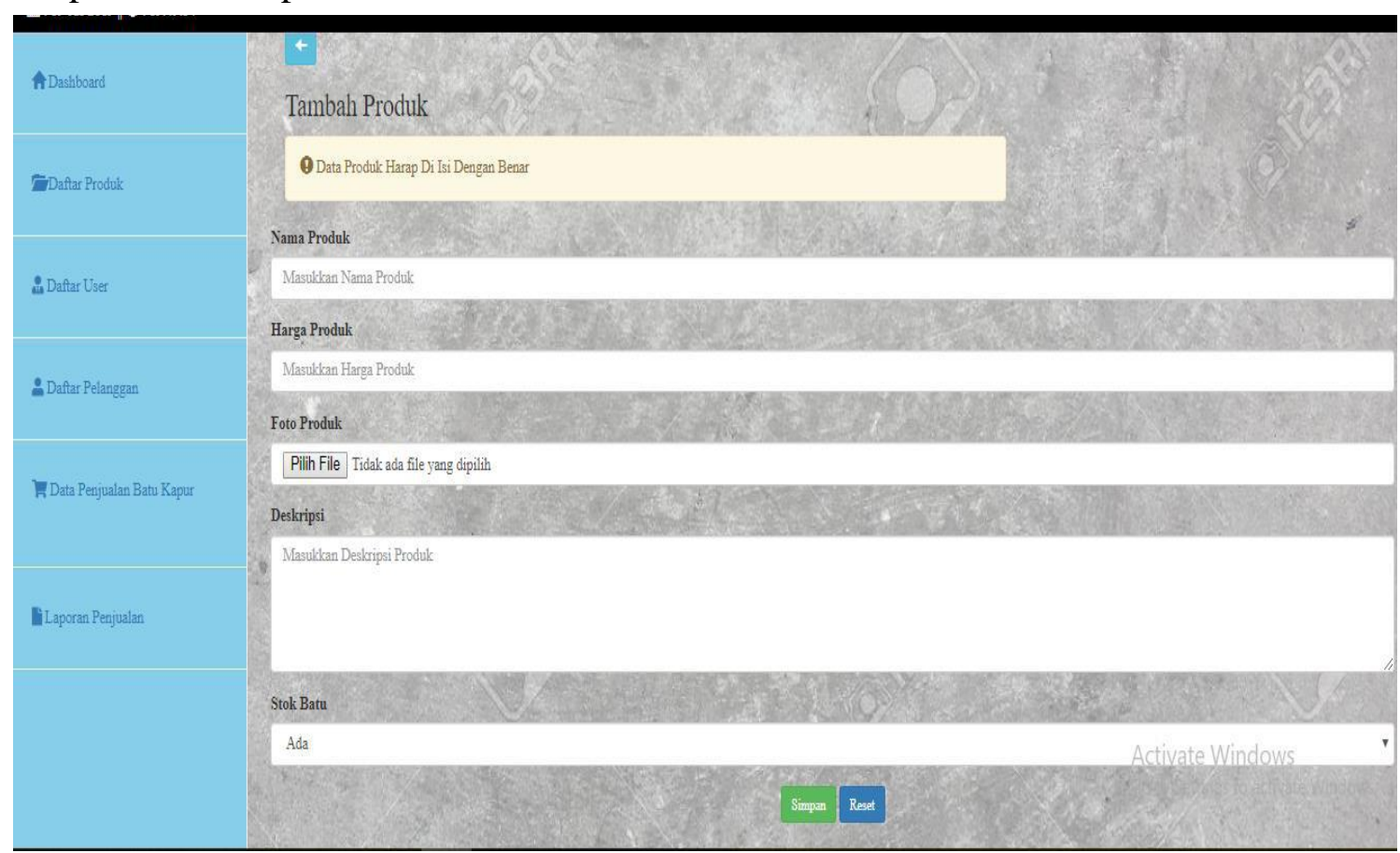

Gambar 19. Tampilan tambah produk

\section{Penutup}

Berdasarkan hasil penelitian dan pembahasan yang telah dilakukan pada sistem informasi penjualan batu kapur, maka dapat disimpulkan bahwa :

1. Dengan adanya sistem ini perusahaan dapat terhindar dari kehilangan dan rusaknya data-data penjualan serta pembuatan laporan dengan mudah.
2. Pelanggan dapat upload foto pembayaran untuk memberitahu kepada penjual atau admin jika sudah melakukan pembayaran.

3. Memberikan informasi kepada pengunjung tentang ketersedian batu kapur yang dijual di CV. Batu Jaya Abadi, Penjualan batu kapur dapat dilakukan selama 24 jam.

\section{Daftar Pustaka}

Abdullah, R. (2016). Easy \& Simple Web Programming. Jakarta: PT Elex Media Komputindo.

Andharsaputri, R. L. (2017). Perancangan Sistem Informasi Penjualan Produk Konveksi Dengan Menerapkan Metode System Development Life Cycle. Jurnal Bianglala Informatika, 56-65.

Backtiar, M. S., \& Supriatna, A. D. (2015). Pengembangan Sistem Informasi Penjualan Batu Akik Market Place Kiara Gemstone. Jurnal Algoritma Sekolah Tinggi Teknologi Garut, 1-8. 
Deti, L. K., \& Mulyono, H. (2017). Analisis Dan Perancangan Sistem Informasi Penjualan Dan Pemesanan Plywood Berbasiskan Web Pada PT. Kumpeh Karya Lestari Jambi. Jurnal Managemen Sistem Informasi, 303-317.

Eka Pratama, I. A. (2014). Sistem Informasi dan Implementasinya. Bandung: Informatika Bandung. 